Arab Univ. J. Agric. Sci., Ain Shams Univ., Cairo, 14(1), 47-58, 2006

\title{
EFFECT OF BROAD BEAN MOTTLE VIRUS INFECTION ON FABA BEAN NODULATION AND EFFICIENCY OF $\mathrm{N}_{2}$-FIXATION
}

[3]

\author{
Hanaa H.A.Gomaa' ${ }^{1}$ M.M. Hazaa ${ }^{2}$; Kh.A. El-Dougdoug ${ }^{3}$ and \\ M.H. Abdel-Ghaffar ${ }^{3}$
}

\begin{abstract}
Plant growth and root nodules of infected Faba bean plants with broad bean mottle virus were significantly reduced in plant height, leaf area, dry matter, number and size of nodules in comparison with healthy ones. As well Leghaemoglobin content and Nitrogenase activity were reduced in infected nodules at 45 days after BBMV inoculation. The amount of $\mathrm{N}_{2}$-fixed as expressed by acetylene reduction was reduced considerably by $38.8 \%$. Nitrogen content as an indicator for the efficiency of $\mathrm{N}_{2}$-fixation was reduced in shoots, roots and root nodules of infected nodulated plants as compared with healthy nodulated ones. Differences between bacteroids in healthy and in BBMV infected cells were no longer apparent. These differences include: (i) a decrease in endocytotic and exocytotic vesiculation on the membrane envelope of the bacteriods and on plasma membrane of bacteroidal cells, (ii) a decrease in number of vesicles in the space between the bacteriod and the membrane envelope. The possible significance of these changes relative to the decreased efficiency of $\mathrm{N}_{2}$-fixation was discussed.
\end{abstract}

Keywords: Faba bean plants, Rhizobia, Broad bean mottle virus, Leghaemoglobin, Nitrogenase, $\mathrm{N}_{2}$-fixation.

\section{INTRODUCTION}

Rhizobial root nodules of legumes plants appear to be affected by viruses, for it is known that virus diseased legumes plants produce smaller, fewer and less effective root nodules than healthy plants (Tu, 1977; Guy et al 1980 and Ishac et al 1983). It also is known that the virus is actually present in root nodule cells of infected plants (Tu, 1977). However, little is known about the effect of virus infection on the Rhizobia in situ.

1- Department of Botany, Faculty of Science, Suez Canal University, Ismailia, Egypt

2- Department of Botany, Faculty of Science, Banha, University, Qalubia, Egypt

3- Department of Agric. Microbiology, Faculty of Agriculture, Ain Shams University Shobra El-Kheimia, Cairo, Egypt

(Received September 7, 2005)

(Accepted November 14, 2005) 
Yield and plant weight reduction in plants infected by soybean mosaic virus (SMV) (Tu, 1973; Ishac et al 1983) and bean pod mottle virus (BPMV) (Tu, et al 1970) have been attributed both to photosynthetic reduction and reduced nodulation. Although reduction of nodule size, number and fresh weight have been showed in SMV-infected soybean plants (Ishac et al 1983). It is not known if the efficiency of $\mathrm{N}_{2}$-fixation by those nodules has been impaired-variations in size and numbers of nodules which may not be important factors in plant growth without knowing their efficiency in $\mathrm{N}$-fixation. Increased efficiency could offset any deleterious effects of reduction of size and number of nodules.

Broad bean mottle virus (BBMV) is belonging to genus bromoviruses. It transmits by mechanical inoculation, grafting and insect; but not transmits by seeds. The virion is isometric, non enveloped, $26 \mathrm{~nm}$ in diameter and rounded (Brunt et al 1996).

Few reports have shown the effect of Broad bean mottle virus (BBMV) on growth retardation, leghaemoglobulin content and Nitrogenase activity. Consequently, the effect of BBMV infection on the efficiency of $\mathrm{N}_{2}$-fixation and ultrastructure of bacteroidal cells in root nodules were not yet study in detail. Therefore the present study aimed to illustrate such effect.

\section{MATERIAL AND METHODS}

An isolate of BBMV and strain of Rhizobium .leguminosarum were obtained from Agric. Microbiology Dept., Fac. of Agric., Ain shams Univ. The Faba bean cv. Giza 143 was used as suscepti- ble host to BBMV infection and R. leguminosarum inoculation.

The experiment was done in pots under green house conditions using sterilized soil in complete randomized design. Seeds of Faba bean were treated with cell suspension $\left(10^{10}\right.$ cell $\left./ \mathrm{ml}\right)$ of $R$. leguminosarum using $2 \mathrm{ml}$ /one gram of seeds. BBMV was mechanically inoculated at first trifoliate leaf stage. The treatments of experiment as follows:

I. Uninoculated, healthy plants.

II. Inoculated plants with $R$. leguminosarum.

III. Mechanically inoculated plants with BBMV.

IV. Inoculated plants with $R$. legminosarum and infected with BBMV.

Number of the plants for each treatment was 50 plants ( 5 in each pot). The parameters and representative samples from leaves, shoots, roots, and root nodules were taken for each treatment, and the following parameters were estimated:.

1- Virus concentration in leaves, roots and nodules was biologically assayed using Chenopodium amaranticolor as local lesion host, at 15, 30, 45, 55 days post BBMV inoculation (Ross, 1967). An equal weighty top leaves, roots and nodules of BBMV inoculated plants were extracted in $0.01 \mathrm{M}$ phosphate buffer, $\mathrm{PH} 7.0(1 \mathrm{ml}$ buffer per gram tissues). The $10^{-1}$ dilution as well as the crude extract were mechanically inoculated on half leaves of Ch. Amaranticolor using Latin square design. Local lesions were counted 7 days after virus inoculation.

2- The morphological (plant height and leaf area) and chemical parameters were done on ten plants from each treatment. Leaf area was calculated 
by the relationship between weight of calico paper of about 10x10 cm and the weight of the unit area. Number, size and dry weight of nodules were calculated. Size of nodules were measured by displacement of water.

3- Assessment of nitrogenase activity in nodules was determined according to Dart and Harris (1972). Two $\mathrm{ml}$ of gas withdrawn from syringes contained $0.2 \mathrm{gm}$ fresh nodules and injected with acetylene and incubated at $30^{\circ} \mathrm{C}$ for one hour and assayed for ethylene concentration using UNICAM gas liquid chromatography model 104 felted with dual flame ionization detectors and a $150 \mathrm{~cm}$ long and $0.4 \mathrm{~cm}$ stainless steal column felted with $10 \%$ of $\mathrm{Na}_{3} \mathrm{PO}_{4}$ on spherosil XOP 075, 100-200 mesh prepared by Pekmen Elmar Company, Bodensee Werks F.P. Germany. Standard curve of the used ethylene was made by injection $1200 \mu \mathrm{C}_{2} \mathrm{H}_{4}$. A linear relation between ethylene concentrations and ethylene peak heights was obtained for each attenuation. The results were presented as $\mu$ moles $\mathrm{C}_{2} \mathrm{H}_{4}$ / weight / h. multiplying by the conversion factor 3 gives the equivalent $\mu$ moles of $\mathrm{N}_{2}$-fixed. The micromoles of $\mathrm{N}_{2}$-fixed multiplied by 28 gives micrograms $\mathrm{N}_{2}$-fixed. It was calculated as micrograms /pot / h.

4- Legheamoglobin content in nodules was determined according to Tu $\boldsymbol{e t}$ al (1970). One gram of frozen nodules was homogenized in $5 \mathrm{ml}$ of $0.1 \mathrm{~N}$ $\mathrm{KOH}$ and centrifuged at $7500 \mathrm{rpm}$ for $10 \mathrm{~min} .1 .5 \mathrm{ml}$ of supernatant was mixed with $1.0 \mathrm{ml}$ distilled water and $0.5 \mathrm{ml}$ of $2 \mathrm{~N} \mathrm{KOH}$. The $0.1 \mathrm{gm}$ of $\mathrm{Na}_{2} \mathrm{~S}_{2} \mathrm{O}_{2}$. After $10 \mathrm{~min}$ from mixing, optical density of legheamoglobin was measured at optical density 537, 557 and $577 \mathrm{~nm}$. The O.D. for legheamoglobin was calculated using the formula of OD557= $1 / 2($ OD537 + OD577).

5- Ultrastructure of bacteroidal cells was examined according to method described by Abdel-Ghaffar (1994). Nodule discs about $1 \mathrm{~mm}$ were cut and fixed for $4 \mathrm{~h}$. in $0.08 \mathrm{M}$ cacodylate buffer, $\mathrm{pH} 7.4$ containing 5\% gutaraldehyde and $4 \%$ paraformaldehyde. The fixed specimens were washed three times at half-hour intervals with $0.1 \mathrm{M}$ cacodylate buffer, $\mathrm{pH}$ 7.4 containing $3 \%$ sucrose. The samples were post fixed in $1 \%$ osmium tetroxide dissolved in a solution of 0.1 $M$ cacodylate buffer and 2\% sucrose. Following three half-hour washes in $0.1 \mathrm{M}$ cacodylate buffer-3\% sucrose, $\mathrm{pH}$ (7.4). The samples were dehydrated in alcohol series, sequentially followed by propylene oxide plus epoxy resin $(1: 1, \mathrm{v} / \mathrm{v})$ and finally embedded in epoxy resin. Ultrathin sections were cut and stained with uranyl acetate then lead citrate, and examined in Zeiss $10 \mathrm{C}$ transmission electron microscope at National Research Center, Giza, Egypt.

\section{RESULTS}

BBMV concentration was significantly reduced in leave, nodule and roots of infected plants (IV) in comparison with non infected nodulated plant (Treatment III) (Table 1), when estimated as a local lesions number of Ch. amaranticolor. Generally BBMV concentration was increased after 45 days post inoculation in leave, root and nodules. 
Table 1. Effect of R. leguminosarum inoculation on BBMV concentration as indexing by local lesion on Ch. Amaranticolor

\begin{tabular}{|rcccccccccccc|}
\hline \multirow{2}{*}{ Treatment } & \multicolumn{4}{c}{ Leaves } & \multicolumn{4}{c}{ Roots } & \multicolumn{3}{c|}{ Nodules } \\
\cline { 2 - 15 } periods & \multicolumn{2}{c}{ III } & \multicolumn{2}{c}{ IV } & \multicolumn{2}{c}{ III } & \multicolumn{2}{c}{ IV } & \multicolumn{2}{c|}{ IV } \\
\cline { 2 - 14 } & $10^{-1}$ & mean & $10^{-1}$ & mean & $10^{-1}$ & Mean & $10^{-1}$ & mean & $10^{-1}$ & Mean \\
\hline 25 & 14.35 & 12.43 & 15.15 & 12.20 & 12.50 & 10.63 & 11.25 & 8.25 & 4.75 & 3.58 \\
35 & 20.75 & 17.75 & 17.10 & 14.25 & 13.75 & 11.50 & 12.65 & 9.95 & 7.95 & 6.10 \\
45 & 19 & 18.75 & 20.50 & 15.87 & 11.25 & 14 & 8.12 & 12.6 & 13.25 & 12 \\
55 & 17.25 & 14.88 & 12.25 & 11.50 & 15.75 & 14.03 & 14.2 & 17.85 & 10.70 & 8.58 \\
Mean & 17.83 & 15.95 & 16.25 & 13.57 & 13.31 & 11.54 & 11.56 & 9.23 & 9.16 & 7.56 \\
\hline
\end{tabular}

III - infected with BBMV only

IV - inoculated with $R$. leguminosarum and infected with BBMV

LSD Treatments period Treatments period

$\begin{array}{lllll}5 \% & 1.32 & 1.75 & 1.02 & 0.95\end{array}$

$\begin{array}{lllll}1 \% & 2.35 & 3.20 & 1.95 & 1.75\end{array}$

Data of plant height, and leaf area were recorded in (Table, 2). It was found that, infected Faba bean plants with BBMV gave significant reduction in plant height. The plants inoculated with $R$. leguminosarum (II) showed the heighest increase in plant height in comparison with control after 55 days in comparison with plants infected with BBMV(III) and those inoculated with $R$. leguminosarum and infected with BBMV(IV). The rate of such increase was found to be (Table, 2) $21.6 ; 41.7 ; 26.5$ and $21.6 \%$ respectively.

Concerning leaf area, it was noticed that plants infected with BBMV (III) showed significant reduction of leaf area in comparison with control (I), inoculated $R$. leguminosarum (II) and infected with BBMV (IV) at different periods of plant growth. Such reduction of leaf area of treatment III compared with treatment IV was found to be $50,65,21$ and $25 \%$ respectively.
Results in Table (3) showed that plants infected with BBMV(III) and it which inoculated with $R$. leguminosarum (IV) had decreased in dry matter. The reduction was found to be significant in first and fourth periods compared with control plants (I) and (II) respectively. The total nitrogen percentage of broad bean shoots was found increased nonsignificantly in the case (IV) of infected plants with BBMV (III) and it which inoculated with $R$. leguminosarum in comparison with control plants (I) and a bacterized plants (II) respectively. It was found that, plants bacterized and inoculated with BBMV increased nonsignificantly at the all periods (Table 3 ). BBMV- infection affected on nodulation and nitrogen fixation. It was found significant reduction in number, size and dry matter of nodules in infected plants with BBMV (IV) compared with non-infected one (II). Such increase was found in the rate of 43; 45 and $93 \%$ (Table 4). 
Table 2. Effect of BBMV on plant height and leaf area of Faba bean plants

\begin{tabular}{|c|c|c|c|c|c|c|c|c|}
\hline \multirow{2}{*}{$\begin{array}{l}\text { Days post } \\
\text {-BBMV } \\
\text { infection }\end{array}$} & \multicolumn{4}{|c|}{ Plant height $(\mathrm{cm})$} & \multicolumn{4}{|c|}{ Leaf area $\mathrm{mm}^{2}$} \\
\hline & I & II & III & IV & I & II & III & IV \\
\hline 25 days & 28.75 & 32.50 & 26.50 & 29.75 & 65.5 & 180.5 & 63.21 & 95.10 \\
\hline 35 days & 32.50 & 38.50 & 30.75 & 33.50 & 110.80 & 228.5 & 95.15 & 157.20 \\
\hline 45 days & 35.70 & 41 & 30.50 & 33.95 & 152.7 & 243.5 & 145.30 & 175.30 \\
\hline 55 days & 37 & 45 & 31.75 & 35.75 & 185.4 & 259.3 & 145.4 & 182.20 \\
\hline Mean & 33.49 & 39.25 & 29.87 & 33.24 & 128.1 & 217.95 & 112.26 & 152.70 \\
\hline
\end{tabular}

I - healthy plants (control)

II - healthy plants and inoculated with $R$. leguminosarum.

III - infected plants with BBMV.

IV - inoculated plants and infected with BBMV.

Mean from 10 plants

LSD Treatment period Treatment period

$\begin{array}{lllll}5 \% & 1.25 & 1.75 & 3.75 & 4.25\end{array}$

$\begin{array}{lllll}1 \% & 2.10 & 2.65 & 5.25 & 6.62\end{array}$

Table 3. Effect of BBMV infection on dry matter and total nitrogen content of Faba bean plant

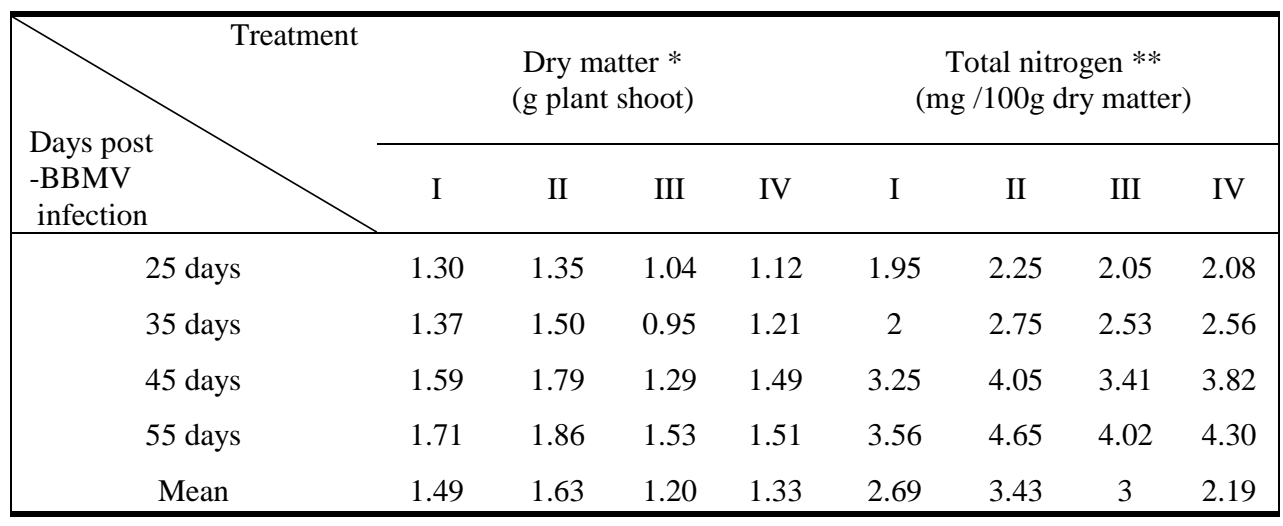

* Dry matter content calculated as mg /plant shoot

** Total nitrogen content percentage calculated as mg / $100 \mathrm{~g}$ dry matter.

$\begin{array}{lccc}\text { LSD } & \text { Treatments } & / & \text { Treatment } \\ 5 \% & 0.25 & 0.65 \\ 1 \% & 0.40 & 0.80\end{array}$

Arab Univ. J. Agric. Sci., 14(1), 2006 
It was clear from data represented in Table (4) that infected nodules had considerable increase in total nitrogen percentage in comparison with healthy nodules (II) such increase was found to be $4,10,80$ and $5 \%$ after $25.35,45$ and 55 days.

Nodules of BBMV- infected plants showed significant reduction in both leghaemoglobin content and nitrogenase activity in comparison with those formed from healthy plants (Table 4). The percentage of reduction in leghaemoglobin content was found to be $17,15,52$ and $33 \%$ at the $25,35,45$ and 55 days respectively. The reduction in nitrogenase activity was found to be $28,40,46$ and $41 \%$ respectively after the same previous periods.

Data represented in Table 4 showed that, both treatment (II) and (IV) gave the highest amount of $\mathrm{N}_{2}$ - fixed at 55 days. At the same period significant reduction in the quantity of the $\mathrm{N}_{2^{-}}$fixed was observed infected nodulated plants(IV) by the rate $25,42,46$ and $39 \%$ comparison with healthy nodulated plants (II).

The micrographs that are presented, show differences between healthy and BBMV-infected bacteroidal cells, which are most noticeable at early stages. Figure(1) is a low magnification micrograph of a BBMV-infected bacteriodal cells. The presence of BBMV particles in the BBMV-infected bacteroidal cell in readily discernible Figure (2). One obvious and important difference in the greater space between the bacteria and the ME in healthy cells than in BBMV-infected cells (compare Figure 3 with Figure 4): this may be indicate Leghaemogloin is located in the space between the symbiotic bacteria and the ME in the bacteroidal cells. In these spaces a network of lightly stained fibrillar material is clearly observed in the bacteroid cells in healthy root nodules.

A second difference is the vesicles in the space between the bacteria and the $\mathrm{ME}$ in healthy bacteroidal cells are more numerous than those in cells of plants infected with BBMV (Figure 3 and 4). Assuming that the vesicles are related to endocytosis and exocytosis, then a higher vesicle density in bacteroidal cell healthy would indicate a higher movement of material between the bacteria and the host cytoplasm. A third difference is healthy cells have a much larger amount of unevenly thick amorphous layer of electronopaque material lining the inside of the ME (Figure 4 asterisk).It is these electron-dense portions of the ME the protrusions are formed (Figure 4). A fourth difference is in the concentration of vesicles associated with the plasma membrane of the bacteroidal cell. These results suggest a higher rate of material movement in and out of the bacteroidal cells.

\section{DISCUSSION}

In the present study, biological assay indicates that inoculation of broad bean plants with $R$. legumonisrum clearly reduced concentration of BBMV in leaves and roots. This reduction may be due to the increase in plant growth, chlorophyll content of nodulated infected plants (El-Dougdoug, 1982) and have decrease in susceptibility especially during the latter stage of infection(55 days). Increased pigment in less susceptible $\mathrm{IR}_{2} \mathrm{O}$ of rice cultivar during the later stages of infection was reported by (Stidanar, et al 1978) who added that the cytokinin activity in $\mathrm{IR}_{2} \mathrm{O}$ was $69 \%$ higher than in healthy plants. 
Figure 1a. A portion of a bacteroidal cells of rhizobial inoculation in healthy root nodule, with clear view of both vesicles and protrusions on ME of the bacteroid. Note there is a large space between the EM and the bacterium. Figure 1b: portion of root nodule cells infected with BBMV and rhizobial infection threads. Showing the presence of extensive of EM, elongation of mitochondria and virus aggregate. 
Figure 2a. Higher magnification of figure $1 \mathrm{~b}$ showing details of bacteroids. The space between the bacteroid and the ME is very narrow. Figure $2 \mathrm{~b}$. A portion of a bacteroidal cell at the early stage of rhizobial infection in healthy root nodule showing the presence of vesicles and protrusions on the ME of the bacteroid. There is a large space between the ME and the bacterium. 
The highest BBMV concentration in Faba bean root nodules was found 45 days post-infection, this gives evidence that BBMV could multiply inside the nodules. Tu (1975) reported the same conclusion using thin sectioning and freeze fracturing techniques in scanning electron microscopy. On the other have the decrease in BBMV concentration in roots may be explained by the reduction in water uptake. A correlation between reduction in water uptake and increase of root resistance was found by Lindsey and Gudauskas, (1974).

Plant height and leaf area were significantly reduced in BBMV infected plants and inoculated with $R$. legumonisrum. This reduction may be the cause of subsequent reduction in photosynthetic activity (Orellana et al 1980). The latter is strongly correlated to the content of chlorophyll. Infected nodules were found to contain significantly higher percentage of both dry weight and total nitrogen. This increase may be due to the lower assimilation of carbohydrate in $\mathrm{N}_{2}$-fixation process in diseased nodules since the number of bacteroidal cells was reduced in comparison with healthy ones (Tu, 1977).

Roots of infected Faba bean plants were contained lower dry weight and higher percentage of total nitrogen than both nodulated and non-nodulated healthy plants. Cowpea plants infected with southern bean mosaic virus were found to increase total nitrogen (Mall $\boldsymbol{e t}$ al 1980; Singh et al 1980 and ElDougdoug, 1982). A considerable decrease in dry matter content of southern bean mosaic virus was found by (Singh and Singh, 1980). It could be concluded that BBMV is a significant factor through its effect on plant growth and the Faba bean-Rhizobium symbiosis
(Orellana et al 1980 and El-Dougdoug, 1982)

Rhizobial root nodules of broad bean plants appear to be affected by BBMV, for it is known that BBMV. Diseased broad bean plants produce smaller, fewer and less effective root nodules than healthy plants (Tu et al 1970). It is also known that the virus is actually present in root nodule.

\section{REFERENCES}

\begin{abstract}
Abdel-Ghaffar, M.H. (1994). Studies on Maize Dwarf Mosaic Virus, pp. 42-45. Ph.D. Thesis, Dept. of Agric. microbiology, Faculty of Agric., Ain Shams University, Cairo, Egypt.
\end{abstract}

Brunt, A.; K. Crabtree; M. Dallwitz; A. Gibbs and L. Watson (1996). BBMV In: Brunt, A.; Crabtree, K.; Dallwitz, M.; Gibbs, A. and Watson, L. (eds.): Viruses of Plants. CAB International, pp. 252253.

Dart, P.J. and D. Harris (1972). Assay of Nitrogenase activity by acetylene reduction. International Atomic Energy Agency Tech. Rep., 149: 85-100.

El-Dougdoug, Kh.A. (1982). Effect of Virus Infection on Nodulation and $\mathrm{N}_{2^{-}}$ Fixation of Soybean Plants. p. 114. M.Sc. Agric. Microbiology, Dept., Fac. of Agric. Ain Shams Univ., Cairo.

Guy, P.; A. Gibbs and K. Harrower (1980). The effect of white clover mosaic virus on nodulation of white clover (Tribolium repeas L.cv. lactino). J. Agric. Res., 31: 207-311.

Ishac, Y.Z.; S.I. El-Afifi; M.A. Abou El-Nasr and Kh.A. El-Dougdoug, (1983). Interaction between Rhizobium japonicium and soybean mosaic virus (SMV) infection in soybean plants (I) 
Chlorophyll and carbohydrate contents. Egypt J. Microbiol. Special Issue, 77-85. Lindsey, D.W. and R.T. Gudauskas (1974). Effects of Maize dwarf mosaic virus on water relations of corn. Phytopathology, 65: 434-440.

Mall,V.R.; M.P. Diwaker and F.S. Potll (1980). Effect of cowpea tobacco mosaic virus (TMV,C) infection on growth nodulation and nitrogen fixation in cowpea. Indian Journal of Mycology and Plant Pathology 9(1): 126-127.

Orellana, R.G.; D.F. Weber and P.B. Cregan (1980). $\mathrm{N}_{2}$-fixation competence of Rhizobium japonicium strains in soybean infected with tobacco ring spot virus. Physiology Plant Pathology. 17: 381-188.

Ross, J.P. (1967). Effect of single and double infections of soybean mosaic bean mottle viruses on soybean yield and seed characters. Plant Dis. Reptr. 52: 344-348. Singh, R.; H.C. Singh and H. Ganglulee (1980). Metabolic changes due to water melon mosaic virus infection in bottle gourd fruits. Indian Journal of Mycology and Plant Pathology 9(1): 89-90.
Singh, A.K. and R.B. Singh (1980). Alternations in protein yield and protein quality in urd bean infected by southern bean mosaic virus. Annale de Phytopath. 12(2): 131-138.

Stidanar, R.; S.K. Mohanty and Anjuneyulu (1978). Physiology of rice tungro virus disease increased cytokinine activity in tungro infected rice cultivars. Physiology Plantarum, 4: 363-366.

Tu, J.C. (1973). Electron microscopy of soybean root nodules infected with soybean mosaic virus. Phytopath. 63: 10111017.

Tu, J.C. (1975). Rhizobial root nodules of soybean as revealed by scanning and transmission electron microscopy. Phytopath. 65: 447-454.

Tu, J.C. (1977). Effects of Soybean Mosaic Virus Infection on Ultrastructure of bacteriodal cells in soybean root nodules. Phytopath. 67: 199-205.

Tu, J.C.; R.E. Ford and S.S. Quinuones (1970). Effect of Soybean Mosaic Virus and /or bean pod mottle Virus Infection on Soybean Ndulation. Phytopath. 66: 518-523. 


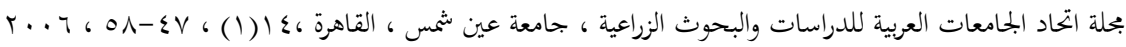
ثأثير الإصابة بفيروس الفول البلابي على تكوين العقد البكتيرية وكفاعة تثبيث النيتروجين في نباتات الفول البلدى

$[r]$

هناء حسين أحمد جمعة' - محمد محمود هزاعَ - خالا عبد الفتاح الاجدج" -

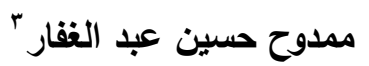

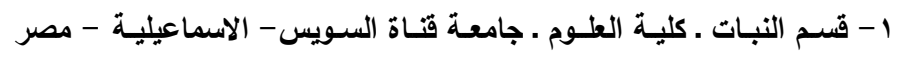

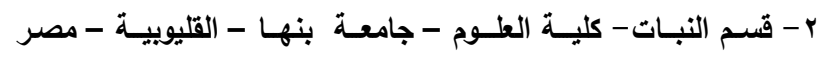

ب- قسم الميكرويبولوجيا الزراعية ـ كلية الزراعة . جامعة عين شمس - شبرا الخيمة - القاهرة - مصر

تتأثر العقد البكتيريـة في النباتـات البقوليـة بالنباتـات السليمة، بالإضـافة للتباين الملحوظ

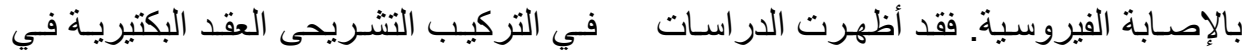
نقص ملحوظ في عدد وحجم العقد البكتيريـة النباتات المصابة عند فحصها بالميكروسكوب الإبه في النباتـات البقوليـة المصـابة بالفيروسـات، الإلكترونسي بالمقارنـة بعقد النباتـات السـليمة.

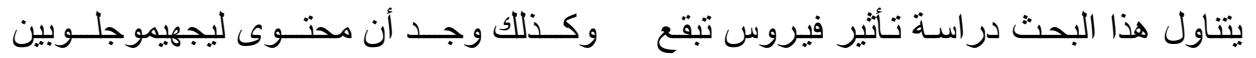

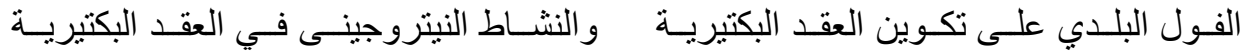
وكفـاءة تثبيت النيتروجين في نباتـات الفول. ينخفض بعد 0 ؛ يوم مـن الحقن بـالفيروس،

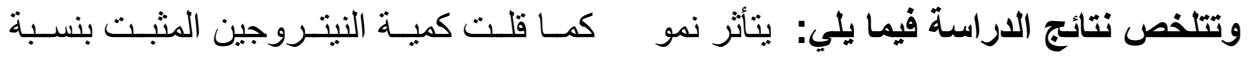

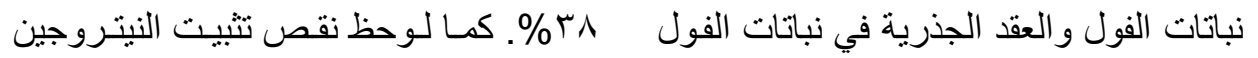

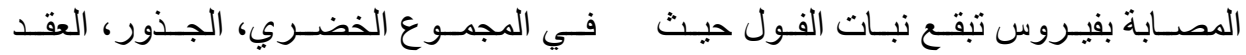

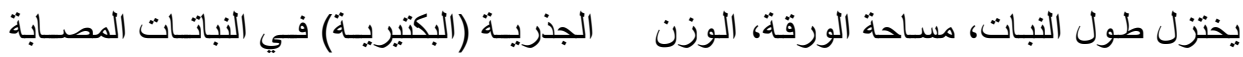

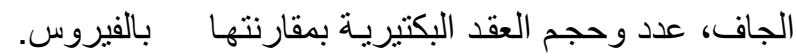

تحكيم: أ.د بـدوى عبد السلام عثمان أ.د عبد المحسن عفيفى أبو زيد علدي 